\title{
HAK ASASI MANUSIA DALAM PERSPEKTIFFILSAFAT HUKUM
}

Oleh:

\author{
Reko Dwi Salfutra*
}

Email: dwisalfutra@gmail.com

\begin{abstract}
Human Rights is a moral principle and its justification is in the philosophical moral.Understanding of human rights in the perspective of philosophical morality is believed to find the correct or at least deepening arguments for understanding the truth of human rights.Pancasila as the ideology of the Indonesian contains the idea that humans are created by God by carrying out two aspects, namely aspects of individuality and aspects of sociality. Therefore, everyone's freedom is limited by the rights of others. This means that everyone has the obligation to recognize and respect the human rights of others.
\end{abstract}

Keywords : Human Right, Philosophy of Law and Concept

\section{A. PENDAHULUAN}

Pembicaraan tentang Hak Asasi Manusia (HAM) tidak terlepas dari adanya pengakuan terhadap adanya hukum alam (natural law) yang merupakan cikal bakal munculnya Hukum HAM. Menurut $G$. Singer sebagaimana yang dikutip oleh Dede Rosyada menyatakan, bahwa "hukum alam merupakan suatu konsep dari prinsip-prinsip umum moral dan sistem keadilan dan berlaku untuk seluruh umat manusia". ${ }^{1}$ Munculnya Hukum HAM yang bersumber dari hukum alam ini pun dinyatakan oleh

* Dosen Tetap Fakultas Hukum Universitas Bangka Belitung.

1 Dede Rosyada, dkk., Demokrasi, Hak Asasi Manusia dan Masyarakat Madani, Prenada Media, Jakarta Timur, 2003, hlm. 202.
Thomas Van Aquino dan beberapa ahli hukum lainnya. Menurut Aquino, bahwa hukum alam bersumber pada hukum Ilahi (Ketuhanan), universal dan tidak berubah dalam ruang dan waktu. Berbeda dengan itu, menurut Grotius menyatakan, bahwa hukum alam muncul ke permukaan dan bertumpu pada akal manusia, terlepas dari setiap pandangan keagamaan. Dalam tulisannya, menyatakan bahwa hal tersebut tidak akan berlaku apabila Tuhan tidak ada. ${ }^{2}$ Hukum alam kaum awam adalah suatu hukum nasional yang mengendalikan semua hubungan antara manusia-manusia, apapun ras

\footnotetext{
${ }^{2}$ Lihat Lili Rasjidi dan Ira Thania Rasjidi, Dasar-dasar Filsafat dan Teori Hukum, PT. Citra Aditya Bakti, Bandung, 2004, hlm. 50.
} 
atau status sosial mereka. Bahkan rajaraja harus tunduk pada undang-undang atau hukum alam yang fundamental, universal, langgeng, lestari dan tidak berubah-ubah yang mengalir dari sifat-sifat kodrat alam manusia itu sendiri. $^{3}$

Kemudian terdapat pula pandangan dari para pelopor hukum lainnya, yakni John Locke (1632-1704) yang menyatakan, bahwa penguasa tidak dapat memerintah secara sewenangwenang sepenuhnya, penguasa tidak dapat melimpahkan kekuasaan membuat undang-undang kepada orang lain, penguasa tidak dapat mengambil atau merampas hak milik seseorang begitu saja tanpa persetujuan yang bersangkutan, penguasa berkewajiban untuk menegakkan keadilan dan mengambil keputusan-keputusan tentang hak kaula-kaula negaranya menurut undang-undang yang tetap, di dalam negara harus ada pemisahan antara kekuasaan legislatif, kekuasaan eksekutif dan kekuasaan federatif yang mengurus hubungan-hubungan luar negeri. John Locke menghidupkan kembali pandangan tentang suatu ikatan kontraktual antara raja dan para kaula negara, seperti Magna Charta di
Inggris pada tahun 1215 maupun Blijde Inkonst pada tahun 1356 di Benua Eropa. Namun di bawah kekuasaan raja-raja yang memegang kedaulatan absolut, hal tersebut terkesampingkan. ${ }^{4}$

Awal perkembangannya, HAM dipahami semata-mata sebagai hak atas kebebasan (freedom). Menurut John Locke, bahwa jika dilihat dari sudut pandang negatif, maka munculnya HAM seperti berniat menghalau campur tangan (intervensi) yang tidak diinginkan terhadap kehidupan pribadi. Misalkan saja menyangkut hak atas hidup, hak atas kebebasan bergerak dan hak atas milik pribadi. Sedangkan dalam sudut pandang positif, menurut $J J$. Rousseau, bahwaseperti adanya hak setiap orang untuk ikut secara aktif menentukan arah perkembangan dan pembangunan masyarakat, misalkan saja hak untuk berserikat dan mengemukakan pendapat baik secara lisan maupun melalui tulisan. Cakupan pengertian HAM ini kemudian berkembang sampai pada suatu kesadaran, bahwa hak atas kebebasan tidak mungkin dinikmati oleh semua orang tanpa adanya kesamaan minimal

${ }^{3}$ Emeritus John Glissen, Sejarah Hukum, PT. Refika Aditama, Bandung, 2007, hlm. 111.

${ }^{4}$ Ibid., hlm. 118. 
dalam masyarakat. ${ }^{5}$ Intinya, dalam konteks ini, maka harus adanya bargaining posistion di antara setiap orang di tengah masyarakat.

Di dalam proses pendefinisian HAM tersebut, sekiranya perlu untuk dipahami makna yang terkandung di dalam hak itu sendiri, sehingga pemahaman terhadap arti penting dari suatu hak tidak dimaknakan ganda. Unsur-unsur hak adalah; pertama, masing-masing hak mengidentifikasikan suatu pihak sebagai pemilik atau pemegangnya. Syarat-syarat pemilikan (conditions of possession) suatu hak barangkali cukup tebatas untuk diberlakukan pada satu orang saja atau cukup luas untuk mencakup seluruh umat manusia. Kedua, hak adalah untuk suatu kebebasan atau keuntungan, sehingga ruang lingkup suatu hak menentukan kegunaan hak tersebut. Ketiga, suatu hak yang ditetapkan secara lengkap akan mengidentifikasi pihak atau pihak-pihak yang harus berperan mengusahakan tersedianya kebebasan atau keuntungan yang diidentifikasikan oleh ruang lingkup hak tersebut. Akhirnya, bobot suatu hak menentukan urutan atau arti

5 Anhar Gonggong, dkk., Sejarah Pemikiran Hak Asasi Manusia di Indonesia, CV. Dwi Jaya Karya, Jakarta, 1995, hlm. 41. pentingnya dalam hubungannya dengan norma-norma lain. ${ }^{6}$

Hak-hak itu secara kodrati inheren, universal dan tidak dapat dicabut. Hak-hak itu dimiliki individu sematamata, karena mereka adalah manusia dan bukan karena mereka adalah kaula hukum suatu negara. Perlindungan terbaik terhadap hak-hak itu terdapat di dalam kerangka yang demokratis. ${ }^{7}$ Jadi, dipahami bahwa pengertian HAM tidaklah statis, melainkan dinamis. Menjadi sangat mungkin sekali akan ada banyak perdebatan mengenai apakah kepentingankepentingan tertentu layak untuk digolongkan sebagai hak dalam ati yang sebenarnya. Proses dialekstis yang digunakan untuk menentukan klaim atau kepentingan yang dapat dilindungi dan yang tidak sangatlah menentukan apabila dianggap mempunyai suatu kualitas yang secara mendasar berbeda dari peraturan hukum lain. ${ }^{8}$ Dengan demikian, untuk memahami makna yang terkandung

\footnotetext{
6 James W. Nickel,Hak Asasi Manusia:Refleksi Filosofis atas Deklarasi Universal Hak Asasi Manusia (Making Sense of Human Rights: Philosophical Reflekstion on the Universal Declaration of Human Rights), Diterjemahkan oleh Titis Eddy Arini, Gramedia Pustaka Utama,Jakarta, 1996, hlm. 19-21.

7 Scott Davidson,Hak Asasi Manusia: Sejarah, Teori dan Praktek dalam Pergaulan Internasional (Human Rights), Diterjemahkan oleh A. Hadyana Pudjaatmaka, Pustaka Utama Grafiti, Jakarta, 1994, hlm. 7.

${ }^{8}$ Ibid., hlm. 9.
} 
dalam HAM secara filsafat moral, maka sekiranya perlu untuk menggunakan sumber-sumber sejarah justifikasi HAM, kemudian mengidentifikasi serta menelaah teoriteori HAM modern dan menganalisis beberapa permasalahan baru didalam teori HAM.

Bagaimana memaknai HAM tentu akan mempengaruhi keputusankeputusan tentang isu-isu mana hakhak yang dianggap sebagai absolut, mana yang universal, mana yang akan diberikan prioritas, dan mana yang bisa dikesampingkan. Dengan permasalahan yang rumit tersebut, akan memungkinkan munculnya pernyataan bahwa pendefenisian HAM merupakan sesuatu yang sia-sia, karena definisi tersebut melibatkan penilaian-penilaian moral yang harus terbukti sendiri dan selanjutnya tidak dapat dipahami.

Banyak batasan tentang HAM. Di dalam Kamus Besar Bahasa Indonesia menyebutkan bahwa "hak" adalah yang benar, milik, kepunyaan; kewenangan; kekuasaan untuk berbuat sesuatu; kekuasaan yang benar atas sesuatu atau untuk menuntut sesuatu; derajat, martabat; wewenang menurut hukum. Hak asasi adalah sesuatu yang oleh sebab itu seseorang (pemegang) memiliki keabsahan untuk menuntut sesuatu yang dianggap tidak dipenuhi atau diingkari. ${ }^{9} \quad$ Seseorang yang memegang hak atas sesuatu, maka orang tersebut dapat memperlakukan sesuatu tersebut sebagaimana dikehendaki atau sebagaimana keabsahan yang dimilikinya. ${ }^{10}$

Namun demikian, melalui tulisan ini sekiranya dapat dirumuskan bahwa HAM merupakan hak yang melekat pada diri manusia yang bersifat kodrati dan fundamental sebagai wujud anugerah dari Tuhan Yang Maha Esa terhadap mahkluk ciptaanNya, yaitu manusia, yang harus dihormati, dijaga dan dilindungi oleh siapapun dan dalam keadaan apapun. ${ }^{11}$ Dengan demikian, hakekat penghormatan dan perlindungan terhadap HAM adalah menjaga keselamatan eksistensi manusia secara utuh melalui aksi keseimbangan antara hak dan kewajiban serta keseimbangan antara kepentingan perseorangan dengan kepentingan

9 Pusat Bahasa Departemen Pendidikan Nasional, Kamus Besar Bahasa Indonesia, Edisi ketiga, Balai Pustaka, Jakarta.

${ }^{10}$ Muladi, Hak Asasi Manusia: Hakekat, Konsep dan Implikasi dalam Perspektif Hukum dan Masyarakat, PT. Refika Aditama, Bandung, 2005, hlm. 228.

${ }^{11}$ Yang dimaksud dengan "dalam keadaan apapun" termasuk keadaan perang, sengketa bersenjata dan atau keadaan darurat. Sedangkan yang dimaksud dengan "siapapun" adalah negara, Pemerintah dan atau anggota masyarakat. Lihat Pasal 4 Undang-Undang Republik Indonesia Nomor 39 Tahun 1999 tentang Hak Asasi Manusia. 
umum. Upaya menghormati, melindungi dan menjunjung tinggi HAM menjadi kewajiban dan tanggung jawab bersama antara individu, pemerintah bahkan cakupan yang lebih besar, yaitu negara.

\section{B. PEMBAHASAN}

\section{Hakekat HAM}

Berfilsafat merupakan suatu bentuk tindakan yang mengenal diri sendiri. Fungsi khusus dari filsafat adalah menemukan takaran atau ukuran yang benar atau paling tidak untuk memperdalam pemahaman akan suatu kebenaran. Namun demikian, masih terdapat pendapat yang menganggap ahli filsafat sebagai hakim yang mencari berbagai pengalaman manusia dan kemudian mengemukakannya yang dituangkan dalam ilmu pengetahuan.

Sehubungan dengan HAM, maka terdapat beberapa alasan khusus dilakukannya kegiatan filsafat terhadap HAM. Pertama, pembenaran terhadap prinsip moral yang merupakan suatu bentuk usaha untuk membuat rasa keterkaitan tentang prinsip-prinsip hubungan interaksi di antara manusia. Suatu sikap ataupun tindakan akan dapat dipahami sebagai tindakan yang salah atau benar dengan cara mencoba memahami dasar filosofis yang membentuknya. Disini akan dapat dipahami, bahwa prinsip moral berpengaruh bahkan menentukan tingkah laku individu atau institusi sosial. Hal ini sesuai dengan pernyataan Piaget yang menyatakan bahwa moral adalah tindakan logis yang mengandung suatu pemahaman yang mengesankan. Kedua, apabila diketahui kekuatan moral dari suatu prinsip HAM, maka dapat diperkuat wewenang hukum internasional HAM sebagai bentuk mekanisme penegakkan HAM yang formal. Ketiga, memahami dasar-dasar filsafat tentang HAM yang akan membantu untuk memikirkan sebuah konsep penerjemahan pandangan terhadap HAM itu sendiri. Keempat, memahami filsafat moral tentang HAM juga akan membantu untuk menggambarkan struktur pemikiran manusia terhadap pendapat tentang hak-hak khusus seperti hubungan hak asasi sesama manusia yang mengatur secara hirarkis ketegangan antara hak-hak asasi tersebut.

Berpijak dari alasan tersebut, maka dapat disimpulkan bahwa 
HAM merupakan seperangkat prinsip-prinsip dasar moral dan pembenarannya terdapat dalam tataran filsafat moral. Dalam konteks ini, filsafat hukum mempersoalkan pertanyaanpertanyaan yang bersifat mendasar dari hukum. Filsafat hukum menghendaki jawaban atas pertanyaan "Apa yang dimaksud dengan hukum?". Filsafat hukum menginginkan kita berfikir secara mendalam dan bertanya pada diri sendiri "Apa pendapat kita mengenai hukum?" Apakah ilmu hukum positif dapat menjawab dua pertanyaan tersebut? Jawabannya adalah dapat. Namun, ilmu hukum tidak dapat memberikan jawaban yang memuaskan, karena jawaban yang dihasilkan tidak akan sekomprehensif bila dijawab oleh filsafat hukum. Ilmu hukum hanya melihat gejala-gejala hukum saja, yang hanya dapat dilihat dengan pancaindra, yang menjelma dalam perbuatan-perbuatan manusia dalam kebiasaan-kebiasaan masyarakat dan dalam kebiasaankebiasaan hukum.

Sehubungan dengan itu, HAM sebagai hak universal sekaligus tidak dapat dicabut cukup menarik sebagaimana yang ditentukan dalam Deklarasi Universal, karena hal tersebut memberikan klaim atas kebebasan, perlindungan, serta pelayanan yang esensial bagi semua orang. Jadi, HAM adalah universal untuk mencegah agar non-warga negara yang tertindas, anggota kelompok minoritas, atau golongan yang dikucilkan dari masyarakat tidak dibiarkan begitu saja tanpa memiliki hak yang dapat dituntut, sehingga adanya penegasan bahwa HAM tidak dapat dicabut dan pemerintah yang menindas tidak dapat seenaknya mengatakan bahwa warga mereka telah mengorbankan atau secara sukarela menyerahkan hakhaknya. $^{12}$

Sebagai bentuk implikasi pengakuan dari HAM ini, maka masing-masing negara dibiarkan secara bebas mengadakan tatanan kelembagaan dan sistem politik yang paling sesuai dengannya, yang paling baik menggambarkan kebutuhan rakyat dan tradisi nasionalnya. Sehingga adanya suatu standar minimum tertentu untuk menghormati yang berkenaan hubungan-hubungan antara warga negara dengan negara,

${ }^{12}$ James W. Nickel, Op. Cit., hlm. 63. 
penghormatan bagi HAM tertentu, beberapa kebebasan pokok tertentu dan hak untuk memiliki pemerintahan sendiri. Jadi, setiap negara bebas untuk memutuskan bagaimana mewujudkan pemerintahannya itu. Demikian pula, masing-masing negara dapat mengadakan pembatasanpembatasan terhadap hak-hak dan kebebasan asasi dari warga negara karena alasan-alasan yang dituntut oleh persyaratan ketenteraman umum dan keamanan, moralitas atau kesehatan nasional. ${ }^{13}$ Satu kenyataan yang agak unik, bahwa penjamin yang akan menjamin penghormatan terhadap hak-hak asasi tersebut adalah negara itu sendiri, akan tetapi yang melakukan pelanggaran setiap hari adalah pihak yang juga diharapkan untuk mengawasi perilakunya sendiri. Pelaku utamanya yang di dalam dirinya ditanamkan segala kekuasaan adalah negara-negara yang berdaulat. Berabad-abad lamanya negara dapat dikatakan memiliki kekuasaan yang hampir tidak terbatas terhadap hidup

13 Antonio Cassese, Ed., Hak-hak Asasi Manusia di Dunia yang Berubah (Human Rights in a Changing World), Diterjemahkan oleh A. Rahman Zainuddin, Yayasan Obor Indonesia, Jakarta, 1993, hlm. 67. matinya individu. ${ }^{14}$ Oleh sebab itu, pemahaman terhadap HAM harus diikuti dengan pengkajian terhadap sumber-sumber HAM itu sendiri. Dengan demikian, akan didapat suatu justifikasi moral yang dapat didorong untuk pemahaman HAM.

Secara konseptual, HAM merupakan suatu pengertian relasional yang bersifat relatif dan terutama diukur dengan perimbangan dengan sesama. Jadi, kebebasan untuk pengembangan diri, pengembangan harmoni dan pengembangan pemilikan manusia hanya dapat dipahami dengan betul dalam perimbangannya dengan manusia lain yang termasuk suatu masyarakat dan satu budaya yang sama. Artinya, dalam suatu masyarakat terdapat kebebasan untuk yang sama di antara semua orang.

Sejalan dengan pandangan tersebut di atas, Pancasila sebagai dasar negara Indonesia mengandung pemikiran, bahwa manusia diciptakan oleh Tuhan Yang Maha Esa dengan menyandang dua aspek, yaitu aspek individualitas dan aspek sosialitas. Oleh karena itu, kebebasan setiap 
orang dibatasi oleh hak asasi orang lain. Ini berarti, bahwa setiap orang mengemban kewajiban mengakui dan menghormati hak asasi orang lain. Kewajiban ini juga berlaku bagi setiap organisasi pada tataran manapun terutama negara dan pemerintah. Dengan demikian, negara dan pemerintah bertanggung jawab untuk menghormati, melindungi, membela dan menjamin HAM setiap warga negara dan penduduknya tanpa adanya suatu diskriminasi ras, budaya maupun agama yang melatarbelakanginya.

\section{HAM dalam Perspektif Filsafat}

\section{Hukum}

HAM merupakan hak dasar yang secara kodrati melekat pada diri manusia dan bersifat universal. Oleh karena itu, harus dilindungi, dihormati, dipertahankan dan tidak boleh diabaikan, dikurangi ataupun dirampas oleh siapapun. HAM meliputi berbagai aspek kehidupan yang dijalani setiap individu dalam fungsi kemasyarakatan yang saling bergantung dan saling terkait. Pemahaman terhadap hakikat HAM merupakan suatu proses yang tidak mudah untuk dipahami. Oleh sebab itu, pemahaman terhadap HAM harus dilakukan dengan pemahaman filosofis.

Era reformasi saat ini, HAM telah menjadi salah satu isu nasional dan mempunyai dampak serta pemikiran yang luas di Indonesia pada khususnya. Terorisme dan korupsi adalah permasalahan yang sedang hangat untuk dibicarakan. Namun demikian, HAM merupakan salah satu permasalahan yang sangat serius untuk mendapat perhatian, sebab dampaknya akan meluas dan dapat menjatuhkan kehormatan bangsa dan negara apabila HAM tersebut diabaikan. Apabila permasalahan HAM yang tidak diselesaikan, pada puncaknya isu tersebut akan berkembang menjadi isu global di dunia. HAM saat ini telah menjadi tuntutan dan sangat perlu untuk diperhatikan oleh pemerintah, sehingga dapat memberikan jaminan kepada masyarakat untuk menghormati, melindungi dan membela serta menjamin hak asasi dari setiap warga negara. Uniknya, setelah reformasi bergulir, korupsi dan pelanggaran HAM semakin menggurita. Birokrasi masih belum banyak berubah, dari mentalitas pelayanan yang buruk dan inefisien, 
praktek suap menyuap masih subur dan berbagai pelanggaran HAM masih banyak terjadi.

Dalam suatu negara hukum yang dinamis, negara ikut aktif dalam usaha menciptakan kesejahteraan masyarakat. Dengan demikian, diaturlah masalah fungsi negara dengan penyelenggaraan hak dan kewajiban asasi manusia itu. Bagaimanapun juga, negara di satu pihak melindungi hak-hak asasi warga negaranya, sedangkan di pihak lain, menyelenggarakan kepentingan umum. Kepentingan umum itu berupa kesejahteraan masyarakat sebagaimana yang diamanatkan oleh Undang-Undang Dasar 1945. Hak-hak asasi manusia tersebut, sebagian telah secara eksplisit dan implisit dimuat dalam Undang-Undang Dasar 1945 yang kemudian dikonkretkan lagi dalam berbagai peraturan perundangundangan. Perhatian terhadap HAM ini, tentunya tidak boleh berhenti sampai pada rumusan aturan-aturan tertulis. Rumusan tersebut masih perlu diuji dengan peristiwa-peristiwa konkret. ${ }^{15}$ Pandangan keliru bahwa

15 Burns H. Weston, "Hak-hak Asasi Manusia”, dalam Hak-hak Asasi Manusia dalam Masyarakat Dunia : Isu dan Tindakan, Cetakan
HAM identik dengan pandangan dunia Barat, tidak boleh menjadi alasan untuk tidak melaksanakan HAM. HAM merupakan persoalan yang universal, tetapi sekaligus juga kontekstual.

Konsep tuntutan hak yang salah memiliki kapasitas untuk menghasilkan tindakan, sehingga akan menemukan suatu bentuk respon dalam diri pendukung HAM yang cemas untuk memfokuskan perhatian publik pada ketidakadilan berbagai penyelewengan HAM. Oleh sebab itu, kemerdekaan perlu dilindungi dari intervensi eksternal yang harus diberikan sebagai status istimewa. Dengan cara demikian, hak-hak fundmental warga negara dapat dilindungi.

Dalam sistem negara-negara otoriter dan totaliter, kebebasan untuk dapat mengekspresikan hakhak dasar sangatlah terbatas atau malahan bisa dikatakan tidak ada sama sekali. Rakyat yang hidup di bawah sistem otoriter dan totaliter sangat tertekan, karena segala bentuk kegiatan yang dilakukan harus dengan sepengetahuan aparat negara. Negara memaksakan pemahaman ideologi resmi negara

1., Editor Todung Mulya Lubis, Yayasan Obor Indonesia, Jakarta, 1993, hlm. 181. 
lewat program indoktrinasi, dan pikiran rakyat dikontrol dan diarahkan sesuai kehendak penguasa. Tidak ada perbedaan atau penafsiran atas persoalan sosial politik yang menyimpang dari apa yang telah digariskan sebagai suatu "kebenaran" negara. Bentuk-bentuk kontrol terhadap pikiran dan pendapat rakyat kemudian mewujud dalam bentuk sensor dan pembredelan pers atau media massa, bahkan tidak dihormatinya hak-hak asasi manusia sebagai hak dasar yang diterima secara kodrati.

Di negara-negara yang menjalankan sistem yang otoriter, berpendapat secara bebas ataupun mengkritik sebuah kebijakan pemerintah, dapat berakibat fatal, seperti ditangkap atau dipenjara. Unjuk rasa yang dipersepsikan sebagai bentuk lain dari protes terbuka terhadap pemerintah, biasanya dihadapi dengan brutal, dipukuli dan ditembak. Para pemimpin dari aksi unjuk rasa harus mempertanggungjawabkan kepemimpinannya di hadapan sidang pengadilan. Tulisan kritis yang mencoba menuliskan keadaan negara sesuai fakta-fakta empiris diberedel dan dilarang keras beredar di masyarakat. Bagi siapa saja yang mencoba untuk mengedarkan buku maupun tulisan yang telah dilarang oleh aparat negara, dapat dikualifikasikan ke dalam perbuatan subversif. Hal ini tentunya sangat ironis, karena sikap kritik disetiap tindakan yang kritis seharusnya sangat berperan dalam mengevaluasi suatu kebijakan yang dikeluarkan oleh negara. Walaupun melakukan tindakan pembatasan atas HAM dari rakyat yang bertentangan dengan demokrasi, namun rezim otoriter selalu mengaku sebagai rezim yang menjalankan sistem pemerintahan yang berlandaskan demokrasi. Demokrasi sebagai sebuah landasan operasional negara, memiliki prinsip-prinsip yang harus dipraktekkan oleh negara yang ingin disebut sebagai negara yang demokratis. Ada prinsip-prinsip dan kriteria umum dari demokrasi yang telah banyak disebutkan dan diperdebatkan oleh berbagai pakar ilmu politik dan ilmu hukum, yang digunakan sebagai parameter yang paling umum dalam menentukan penilaian kadar demokrasi sebuah negara.

Sikap rakyat yang apatis, tidak kritis akibat dari pembatasan- 
pembatasan politik menyebabkan melemahnya kontrol rakyat terhadap penyelenggaran birokrasi. Birokrasi yang tanpa kontrol ini bermuara dengan semakin besarnya penyelewengan - penyelewengan kekuasaan. Usaha perubahan keadaan menuju keadaan yang lebih demokratis yang dilakukan oleh kelompok pro-demokrasi dengan sendirinya akan terus bermunculan. Pada saat ini, perlindungan terhadap pelaksanaan dari HAM akan selalu ditampilkan sebagai tindakan pertama dalam tataran pemerintah yang demokratis. HAM merupakan suatu bentuk pembicaraan yang akan menjadi sorotan dalam pelaksanaan demokratisasi negara. Perlidungan HAM warga negara merupakan parameter pertama yang menentukan kadar demokrasi suatu negara.

Terhadap negara-negara baru, tentu tema identitas budaya memiliki ketertarikan tersendiri. Tema ini membantu mendobrak imperialisme Barat dan memungkinkan negara yang dijajah untuk menonjolkan perbedaan budaya mereka sebagai konsep dasar HAM. Adalah sangat logis bahwa sebagian negara baru ingin menjadikan tradisi budaya mereka sendiri menjadi bagian kehidupan bangsa untuk mengikat individuindividu kedalam integritas dan kohesi semangat kesatuan sosial.

Menanggapi hal semacam itu, filsafat moral universal menegaskan prinsip-prinsip yang melindungi hak-hak asasi kemerdekaan manusia secara universal dan individual, kebebasan, persamaan hak dan keadilan dengan memberikan landasan non-legal kepada mereka. Relativisme membela pengkondisian budaya yang dianggap mencerminkan sejumlah keinginan dan kebaikan yang dibutuhkan para anggotanya dari suatu kelompok budaya. Alasan atau argumen relativisme budaya ini dipakai untuk membenarkan pembatasan-pembatasan dalam tataran hak-hak asasi manusia.

Jadi, dapat disimpulkan bahwa implikasi posisi relativisme terhadap HAM sebenarnya membingungkan bagi banyak teori yang ingin melihat HAM berperan dalam persoalan riil. Oleh sebab itu, kaum relativis mencari justifikasi selain dari pada teoriteori universalisme untuk menegaskan HAM secara nyata 
sebagai landasan relativisme. Dengan demikian, sekiranya dapat dipahami bahwa membicarakan definisi HAM dapat menghasilkan suatu kesimpulan yang berbeda pula. Hal ini tergantung pada dari mana kita memandang konsep HAM itu sendiri.

Konsep HAM sebagai manifestasi dari kehidupan budaya bangsa, umumnya mencerminkan kombinasi antara hak bawaan dengan hak perjuangan dan bukan hak triman. Artinya hak-hak yang hendak diwujudkan bukanlah direbut demi kepentingan pribadi, melainkan demi terwujudnya keluhuran budi, harkat dan martabat manusia yang ditandai oleh jiwa merdeka dan saling menghargai dalam tataran pergaulan masyarakat nasional maupun internasional. Hak-hak tersebut sudah pasti merupakan suatu bentuk dari hukum alami bagi umat manusia. $^{16}$

Agar ide ataupun gagasan HAM menjadi suatu kebutuhan dan realitas sosial yang umum, perlu terjadi perubahan mendasar pada anggapan dan praktik-paktik masyarakat. Merupakan observasi

\footnotetext{
${ }^{16}$ Antonio Cassese, Op. Cit., hlm. 238.
}

yang biasa bahwa manusia dimanamana menuntut realisasi dari bermacam-macam nilai guna untuk memastikan kesejahteraan individu maupun kolektif. Tuntutan-tuntutan ini seringkali dikecewakan sehingga menyakitkan oleh kekuatan sosial maupun alam, yang mengakibatkan terjadinya eksploitasi, penindasan, penganiayaan dan bentuk-bentuk perampasan lainnya. Mengakar dari pengamatan ini merupakan awal dari apa yang disebut dengan hakhak asasi manusia dan proses hukum suatu negara. ${ }^{17}$

\section{PENUTUP}

Pemahaman terhadap HAM harus dilakukan melalui pendekatan filsafat hukum, hal ini karena pemahaman akan kebenaran dari suatu perlindungan HAM akan dapat diketahui melalui penafsiran secara filosofis. Negara sebagai pemegang kekuasaan harus mampu mengakomodasi perlindungan hak asasi warganegaranya yang telah tertuang dalam peraturan perundangundangan yang telah dirumuskan melalui penafsiran-penafsiran secara filsafati tersebut, baik melalui sosialisasi tentang HAM itu sendiri

\footnotetext{
${ }^{17}$ Burns H. Weston, Op. Cit., hlm. 1.
} 
maupun pada tataran penegakan HAM tersebut dengan bertitik tolak pada teori-teori tentang hak asasi manusia secara universal.

\section{DAFTAR PUSTAKA}

Anhar Gonggong, dkk. 1995. Sejarah Pemikiran Hak Asasi Manusia di Indonesia. CV. Dwi Jaya Karya, Jakarta.

Antonio Cassese, Ed. 1993.Hak-hak Asasi Manusia di Dunia yang Berubah (Human Rights in a Changing World). Diterjemahkan oleh A. Rahman Zainuddin. Yayasan Obor Indonesia, Jakarta.

Burns H. Weston. 1993. "Hak-hak Asasi Manusia".Dalam Hak-hak Asasi Manusia dalam Masyarakat Dunia: Isu dan Tindakan. Cetakan 1. Editor Todung Mulya Lubis. Yayasan Obor Indonesia, Jakarta.

Dede Rosyada, dkk. 2003.Demokrasi, Hak Asasi Manusia dan Masyarakat Madani. Prenada Media, Jakarta Timur.

Emeritus John Glissen. 2007. Sejarah Hukum. PT. Refika Aditama, Bandung.

James W. Nickel. 1996. Hak Asasi Manusia:Refleksi Filosofis atas Deklarasi Universal Hak Asasi Manusia (Making Sense of Human Rights: Philosophical Reflekstion on the Universal Declaration of Human Rights). Diterjemahkan oleh Titis Eddy Arini. Gramedia Pustaka Utama, Jakarta.
Lili Rasjidi dan Ira Thania Rasjidi. 2004.Dasar-dasar Filsafat dan Teori Hukum. PT. Citra Aditya Bakti, Bandung.

Muladi. 2005.Hak Asasi Manusia: Hakekat, Konsep dan Implikasi dalam Perspektif Hukum dan Masyarakat. PT. Refika Aditama, Bandung.

Pusat Bahasa Departemen Pendidikan Nasional.Kamus Besar Bahasa Indonesia.Edisi Ketiga. Balai Pustaka, Jakarta.

Republik Indonesia. Undang-Undang Dasar Negara Republik Indonesia Tahun 1945.

Republik Indonesia.Undang-Undang Nomor 39 Tahun 1999 Tentang Hak Asasi Manusia (Lembaran Negara Republik Indonesia Tahun1999 Nomor 165, Tambahan Lembaran Negara Republik Indonesia Nomor 3886).

Scott Davidson. 1994. Hak Asasi Manusia: Sejarah, Teori dan Praktek dalam Pergaulan Internasional (Human Rights). Diterjemahkan oleh A. Hadyana Pudjaatmaka. Pustaka Utama Grafiti, Jakarta. 